\title{
Investigation on a Blend System of Polymers Containing Uracil and Triazine Groups
}

\author{
Yueqin DuAn, Xudong WAng, Chenxi $\mathrm{LI}^{\dagger}$, and Binglin HE \\ State Key Laboratory of Functional Polymer Materials for Adsorption Separation, \\ Institute of Polymer Chemistry, Nankai University, 300071, Tianjin, P. R. China
}

(Received April 10, 2003; Accepted September 1, 2003)

\begin{abstract}
The synthesis of two new monomers containing a uracil unit and copolymers of the novel monomers with methyl methacrylate is described. Poly(styrene-acrylonitrile) (SAN) was modified by reaction with dicyandiamide in dry dimethyl sulfoxide, so that the acrylonitrile units were partially converted to 2,4-diamino-1,3,5-triazine moieties. The triazine rings in the terpolymer and uracil unit in the copolymer may form complementary triple hydrogen bonding sites. Blends of the copolymer containing uracil and terpolymer containing triazine ring were miscible owing to strong hydrogen bonding interaction between the two polymers. Miscibility and hydrogen bonding interaction of the blend system were investigated by DSC and FTIR.
\end{abstract}

KEY WORDS Uracil / Triazine / Hydrogen Bonding / Miscibility /

There has been considerable interest in the study of polymer blends due to their importance in academic and technical aspects. ${ }^{1}$ Thermodynamically, the miscibility of polymer blends is dependent mainly on mixing enthalpy because the contribution of the combinatorial entropy to the free energy of mixing is negligible. Two dissimilar polymers usually form an immiscible blend. For some immiscible polymer blends, it is possible to induce miscibility when one or both polymers contain interacting groups, ${ }^{2,3}$ such as hydrogen bonding, ${ }^{4-9}$ ion-ion interaction, ${ }^{10}$ charge-transfer, ${ }^{11,12}$ and ion-dipole interaction. ${ }^{13-15}$ Hydrogen bonding plays an important role in the miscibility of polymer blends. ${ }^{4-9,16-19}$ In some cases, the donor (D) and acceptor (A) normally have the capability of forming double or triple hydrogen bonds, and are often structural analogues of the pyrimidine-purine nucleic acid bases. Stadler et al. have grafted (4-carboxyphenyl)urazole groups on to polybutadiene to give a two-dimensional network formed by self-association of urazole moieties, ${ }^{20,21}$ while Rebek used melamine to form triple hydrogen-bonded structures with trisimide units. ${ }^{22} \mathrm{~A}$ number of synthetic polymers which serve as nucleic acid models had been designed, and their functionalities have been extensively studied. ${ }^{23-25}$ Most of them have a vinyl-type backbone chain and nucleic acid bases as pendant groups. We reported previously that styrene-divinylbenzene copolymer bearing 2,4-diaminotriazine could adsorb nucleic acid bases in methanol by forming multiple hydrogen bonds between the 2,4-diaminotriazine moiety and nucleic acid base. ${ }^{26}$

In this paper, two novel methacrylate derivatives of uracil were designed and synthesized, and copolymers of the new monomers with methyl methacrylate were prepared. The blends of poly(styrene-acrylonitrile) (SAN) and copolymers containing uracil were immiscible. When SAN was modified to have 2,4-diamino$1,3,5$-triazine, ${ }^{27}$ the blends became miscible, suggesting that the triazine rings and uracil units form complementary pairs of donor-acceptor-donor (DAD) and acceptor-donor-acceptor (ADA) triple hydrogen bonding sites. The interaction may be the main driving force for miscibility.

The miscibility of polymer blends is commonly ascertained through the measurement of the glass transition temperature $\left(T_{\mathrm{g}}\right)$ by differential scanning calorimetry (DSC). A single $T_{\mathrm{g}}$ indicates that the blend system is miscible; otherwise the blend system is not miscible. Recently Fourier transform infrared (FTIR) is used to study hydrogen bonding. ${ }^{28,29}$ In the present paper, DSC and FTIR were used to investigate blend miscibility and hydrogen bonding between the terpolymer, styrene-acrylonitrile-vinyl-2,4diamino-1,3,5-triazine, and copolymer, methyl methacrylate-methacrylate derivative of uracil.

\section{EXPERIMENTAL}

\section{Materials}

Poly(styrene-acrylonitrile) (SAN, containing 25 wt\% AN), dicyandiamide, potassium hydroxide, acrylonitrile, ethanolamine, hydrochloric acid, dimethyl sulfoxide (DMSO), uracil, bromoacetic acid, methacrylic acid, benzoyl chloride, and ethylene glycol are all analytical grade of commercial products.

To whom correspondence should be addressed. 
<smiles>C=C(C)C(=O)Cl</smiles><smiles>C=C(C)C(N)=O</smiles><smiles>C=C(C)C(=O)OC(=O)C(=C)C</smiles>

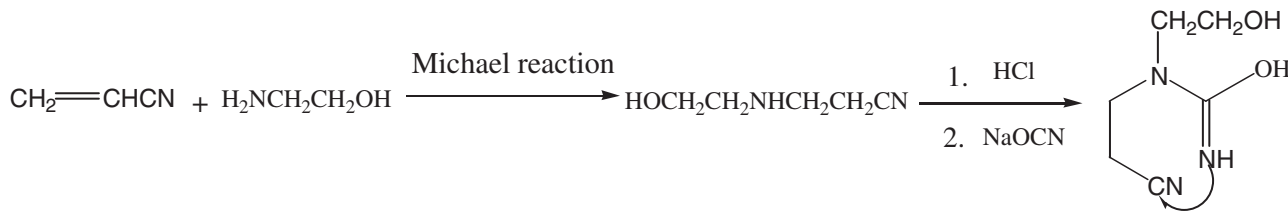<smiles>O=C1CCN(CCO)C(=O)N1</smiles><smiles>C=C(C)C(=O)CC1CCCC1</smiles><smiles>C=C(C)C(=O)OCCN1CCC(=O)NC1=O</smiles>

Scheme 1. Synthesis of monomer I.<smiles></smiles><smiles>O=C(O)Cn1ccc(=O)[nH]c1=O</smiles><smiles>C=C(C)C(=O)OCC(=O)Cn1ccc(=O)n(CC(=O)OC(C)=O)c1=O</smiles>

(II)

Scheme 2. Synthesis of monomer II.

\section{Monomer Synthesis}

Two new monomers containing uracil unit were prepared. The synthesis routes are shown in Schemes 1 and 2.

Synthesis of Monomer I (1-methacryloxy ethyl-5,6-dihydrouracil)

(i) Methacryloyl chloride. Methacryloyl chloride was prepared following the method used by Herbert. ${ }^{30}$ Yield $60 \%$, b.p. $88-90{ }^{\circ} \mathrm{C}$.

(ii) Methacrylic anhydride. To $0.468 \mathrm{~mol}$ methacrylic acid $\left(40.29 \mathrm{~g}\right.$ ), $0.523 \mathrm{~mol} \mathrm{NaOH}$ in $35 \mathrm{~mL} \mathrm{H}_{2} \mathrm{O}$ was added. The mixture was kept at room temperature for $0.5 \mathrm{~h}$, and then diethyl ether $(48 \mathrm{~mL})$ was added. A solution of $0.39 \mathrm{~mol}$ of methacryloyl chloride in $32 \mathrm{~mL}$ diethyl ether was added dropwise to the mixture. On keeping the mixture at $18-20^{\circ} \mathrm{C}$ for $1 \mathrm{~h}$, it was separated into two layers. The upper layer was dried with anhydrous $\mathrm{CaCl}_{2}$. After evaporation of the ether, methacrylic anhydride was obtained by reduced pressure distillation. Yield $80 \%$, b.p. 45-47 ${ }^{\circ} \mathrm{C} / 2 \mathrm{~mm}$. IR (KBr, cm ${ }^{-1}$ ): 1788, 1723, 1636, 1455. (iii) 1-(2-Hydroxyethyl)-5,6-dihydrouracil. This synthesis was carried out according to the method of Inaki et $a l .{ }^{31}$

Ethanolamine $(42 \mathrm{~mL}, 0.70 \mathrm{~mol})$ was added to a 
three-necked flask equipped with thermometer and stirrer. Acrylonitrile $(55 \mathrm{~mL}, 0.84 \mathrm{~mol})$ was added dropwise to the ethanolamine at $0{ }^{\circ} \mathrm{C}$. The mixture was stirred for $1 \mathrm{~h}$. Acrylonitrile unreacted was evaporated and the resulting viscous oily product was dissolved in $3 \mathrm{~N}$ hydrochloric acid $(270 \mathrm{~mL})$. The solution was added dropwise to an aqueous solution of potassium cyanate $(70 \mathrm{~g}, 0.86 \mathrm{~mol})$. After stirring for $24 \mathrm{~h}$ at room temperature, the solvent was evaporated to give an oily residue. The residue was then diluted with methanol $(600 \mathrm{~mL})$, and the precipitate potassium chloride formed was removed by filtration. Aqueous methanolic hydrochloric acid $(100 \mathrm{~mL}$ of conc. $\mathrm{HCl}$ in $300 \mathrm{~mL}$ water and $300 \mathrm{~mL}$ methanol) was added to the filtrate. The solution was refluxed for $2 \mathrm{~h}$. The solvent was evaporated to dryness. The product was extracted from the residue with hot ethanol. The extract was filtered, and the filtrate was cooled to give colorless crystals of product. Yield $75 \%$, mp 143$145^{\circ} \mathrm{C}$.

(iv) 1-Methacryloyloxyethyl-5,6-dihydrouracil (monomer I). Methacrylic anhydride $(11.71 \mathrm{~g}, 0.076 \mathrm{~mol})$ was added to a solution of 1-(2-hydroxyethyl)-5,6-dihydrouracil $(6 \mathrm{~g}, 0.038 \mathrm{~mol})$ in dry pyridine $(50 \mathrm{~mL})$. A small amount of phenothiazine was added to the mixture. The solution was stirred overnight at room temperature. The solvent and excess methacrylic anhydride were removed by distillation under reduced pressure. The product was separated from the residue by column chromatography (mobile elution phase, benzene:ethanol $=5: 1$ ). Yield $75 \%, \mathrm{mp} 78-80^{\circ} \mathrm{C}$. ${ }^{1} \mathrm{HNMR}$ was performed by using a plus-400 Varian UNITY spectrometer. ${ }^{1} \mathrm{HNMR}\left(\mathrm{CDCl}_{3}\right), \delta(\mathrm{ppm})$ : $8.047(\mathrm{~s}, 1 \mathrm{H}), 6.095(\mathrm{~s}, 1 \mathrm{H}), 5.601(\mathrm{~s}, 1 \mathrm{H}), 4.347(\mathrm{t}$, $2 \mathrm{H}), 3.724(\mathrm{t}, 2 \mathrm{H}), 3.519(\mathrm{t}, 2 \mathrm{H}), 2.667(\mathrm{t}, 2 \mathrm{H})$, 1.934 (s, 3H); EA (\%): $\mathrm{C}_{10} \mathrm{H}_{14} \mathrm{~N}_{2} \mathrm{O}_{4}$ Calcd: C 53.17, H 6.19, N 12.39; Found: C 52.97, H 6.10, N 12.46.

Synthesis of Monomer II (1-[(2-Methacryloyloxy)ethoxycarbonyl]methylene uracil)

(i) 1-Carboxymethyl uraci. ${ }^{32}$ Uracil $(3.36 \mathrm{~g}, 30 \mathrm{mmol})$ and potassium hydroxide $(6.41 \mathrm{~g}, 115 \mathrm{mmol})$ were dissolved in $20 \mathrm{~mL}$ water and heated to $40-45^{\circ} \mathrm{C}$. A solution of bromoacetic acid $(6.25 \mathrm{~g}, 45 \mathrm{mmol})$ in $10 \mathrm{~mL}$ water was added dropwise to the mixture during $0.5 \mathrm{~h}$. The reaction was continued for $2 \mathrm{~h}$ at this temperature. The mixture was neutralized, refrigerated for $2 \mathrm{~h}$, and filtrated. The filtrate was acidified to a $\mathrm{pH}$ of $1-2$, and refrigerated for $4 \mathrm{~h}$. The precipitate formed was collected by filtration, washed twice with cold water, and dried under vacuum for $24 \mathrm{~h}$. Yield $80 \%, \mathrm{mp}>$ $270{ }^{\circ} \mathrm{C}$. IR (KBr): $2800-3400 \mathrm{~cm}^{-1}$ (broad and strong), ${ }^{1} \mathrm{H}$ NMR (DMSO- $\mathrm{d}_{6}$ ), $\delta$ (ppm): 13.160 (s, $1 \mathrm{H}), 11.361(\mathrm{~s}, 1 \mathrm{H}), 7.610(\mathrm{~d}, 1 \mathrm{H}), 5.584(\mathrm{~d}, 1 \mathrm{H})$, $4.406(\mathrm{~s}, 2 \mathrm{H})$. (ii) 1-(Hydroxyethoxycarbonyl)methylene uracil. To a $100 \mathrm{~mL}$ three-necked flask equipped with stirrer, condenser and thermometer, 1-carboxymethyl uracil ( $3 \mathrm{~g}$, $17.6 \mathrm{mmol})$, ethylene glycol $(30 \mathrm{~mL})$, and a few drops of conc. $\mathrm{HCl}$ were added. The mixture was stirred for $2 \mathrm{~h}$ at $80-90^{\circ} \mathrm{C}$. Ethylene glycol was removed by distillation under reduced pressure. The residue was filtered, washed repeatedly with tetrahydrofuran, and dried under vacuum for $24 \mathrm{~h}$. Yield $78 \%$. ${ }^{1} \mathrm{HNMR}$ $\left(\right.$ DMSO-d $\left._{6}\right), \delta(\mathrm{ppm}): 11.418(\mathrm{~s}, 1 \mathrm{H}), 7.619(\mathrm{~d}, 1 \mathrm{H})$, $5.624(\mathrm{~d}, 1 \mathrm{H}), 4.883(\mathrm{t}, 2 \mathrm{H}), 4.536(\mathrm{~s}, 2 \mathrm{H}), 4.112(\mathrm{t}$, $2 \mathrm{H}), 3.580(\mathrm{t}, 2 \mathrm{H})$.

(iii) 1-[(2-methacryloyloxy)ethoxycarbonyl]methylene uracil (monomer II). 1-(Hydroxyethoxycarbonyl)methylene uracil $(10.1 \mathrm{~g}, 47 \mathrm{mmol})$ was dissolved in dry pyridine $(100 \mathrm{~mL})$. Methacrylic anhydride $(124.1 \mathrm{~g}, 94 \mathrm{mmol})$ was added dropwise. The mixture was stirred for $24 \mathrm{~h}$ at room temperature. The solvent was removed by distillation under reduced pressure. The product was obtained by column chromatography (benzene:ethanol $=5: 1$ ). Yield $75 \%, \mathrm{mp} 124-126^{\circ} \mathrm{C}$. ${ }^{1} \mathrm{H}$ NMR (DMSO-d $\mathrm{d}_{6}$ ), $\delta(\mathrm{ppm}): 11.418(\mathrm{~s}, 1 \mathrm{H}), 7.615$ (d, 1H), $6.042(\mathrm{~s}, 1 \mathrm{H}), 5.705(\mathrm{~s}, 1 \mathrm{H}), 5.615(\mathrm{~d}, 1 \mathrm{H})$, $4.552(\mathrm{~s}, 2 \mathrm{H}), 4.340(\mathrm{~m}, 4 \mathrm{H}), 1.877(\mathrm{~s}, 3 \mathrm{H})$; EA (\%): $\mathrm{C}_{12} \mathrm{H}_{14} \mathrm{~N}_{2} \mathrm{O}_{6}$ Calcd: C 51.06, H 4.96, N 9.93; Found: C 50.88, H 4.81, N 9.86.

\section{Copolymer Synthesis}

Copolymerization of methyl methacrylate (MMA) with methacrylate derivative monomers I or II was carried out in DMSO at $60^{\circ} \mathrm{C}$ using $2,2^{\prime}$-azobisisobutyronitrile (AIBN) as initiator. The copolymers were obtained as white solids after precipitation in methanol, followed by further purification Yield 35$50 \%$. The copolymers with different mol\% of monomer I (or monomer II) in the feed were prepared. The molecular weights of the copolymers were measured by Waters 410 gel permeation chromatography (GPC) at a rate of $1.0 \mathrm{~mL} / \mathrm{min}$ in DMF as effluent flow. GPC was first calibrated using standard samples of polystyrene. The results are shown in Table I.

Table I. Characterization of copolymers of monomer I and II with MMA

\begin{tabular}{cccc}
\hline Copolymers & $\begin{array}{c}\text { Monomer I or II Content } \\
(\mathrm{mol} \%)\end{array}$ & $\begin{array}{c}\mathrm{M}_{\mathrm{w}}\left(10^{4}\right) \\
(\mathrm{g} / \mathrm{mol})\end{array}$ & Polydispersity \\
\hline P1 & $50(\mathrm{I})$ & 23.67 & 1.88 \\
P2 & $33(\mathrm{I})$ & 21.44 & 2.08 \\
P3 & $25(\mathrm{I})$ & 16.70 & 2.03 \\
P4 & $10(\mathrm{I})$ & 18.36 & 1.09 \\
P1 $^{\prime}$ & $50(\mathrm{II})$ & 40.15 & 1.25 \\
P2 $^{\prime}$ & 33 (II) & 30.26 & 1.10 \\
P3' $^{\prime}$ & 25 (II) & 11.24 & 1.15 \\
P4' $^{\prime}$ & $10(\mathrm{II})$ & 9.76 & 1.19 \\
\hline
\end{tabular}




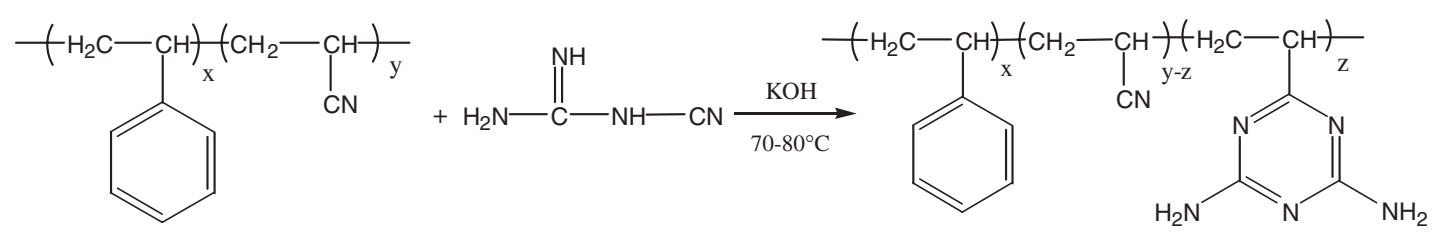

Scheme 3. Modification of poly(styrene-acrylonitrile) (SAN).

\section{Modification of Poly(styrene-acrylonitrile) (SAN)}

Scheme 3 shows modification of poly(styreneacrylonitrile) (SAN). A solution of SAN (1.766 g) in DMSO $(110 \mathrm{~mL})$ was prepared under dry nitrogen. Dicyandiamide (DCDD, $1.682 \mathrm{~g}$ ) and potassium hydroxide $(0.281 \mathrm{~g})$ were added and the mixture was heated to $60-70^{\circ} \mathrm{C}$. Reaction time $(t)$ was controlled at 10 $30 \mathrm{~h}$. The content of triazine ring in the terpolymer increased with reaction time. The mixture was concentrated by distillation under reduced pressure. Poly(styrene-acrylonitrile-vinyl-2,4-diamino-1,3,5-triazine) was obtained after precipitation in methanol, and purification was achieved by redissolving the samples in DMSO and reprecipitating by addition to methanol. The products were dried under vacuum and designated as: SAN-0 $(t=0 \mathrm{~h}$, unmodified $)$, SAN-10 $(t=$ $10 \mathrm{~h}), \operatorname{SAN}-20(t=20 \mathrm{~h}), \mathrm{SAN}-30(t=30 \mathrm{~h})$.

\section{Polymer Blend Preparation}

The copolymers containing uracil and terpolymers (styrene-acrylonitrile-vinyl-2,4-diamino-1,3,5-triazine) were respectively dissolved in DMSO to form $1 \%$ $(\mathrm{w} / \mathrm{v})$ solutions. Equal amounts of copolymer and terpolymer solutions were mixed by dropwise adding the former solution to the later. The mixture was stirred for $3 \mathrm{~h}$ at room temperature and precipitation did not occur. The powdered blends of copolymer/ terpolymer, all regulated at a 50/50 composition in $\mathrm{w} / \mathrm{w}$, were obtained by co-precipitation into water or evaporating the solvent slowly.

\section{Instrumentation and Measurements}

$T_{\mathrm{g}} \mathrm{s}$ of various samples were measured with a NETZSCH DSC 204. $T_{\mathrm{g}}$ s of the copolymers and those of the terpolymers were close, blend samples were treated by the following aging process. ${ }^{33}$ Blend samples for aging were kept at $T_{0}>T_{\mathrm{g}}$ for $5 \mathrm{~min}$ to erase previous history. In most cases, $T_{0}=160^{\circ} \mathrm{C}$. The samples were cooled by quenching in liquid nitrogen, followed by aging for $24 \mathrm{~h}$ at $T_{\mathrm{a}}<T_{\mathrm{g}}$, usually $T_{\mathrm{a}}=60^{\circ} \mathrm{C}$. The samples were quenched by liquid nitrogen again, and DSC scans were carried out from -5 to $200^{\circ} \mathrm{C}$ at $10^{\circ} \mathrm{C} / \mathrm{min}$. The initial onset of change of slope in the DSC curve was taken as $T_{\mathrm{g}}$.

Infrared spectra were recorded on a Bio-Rad FTS 600 Fourier Transform Infrared spectrometer at a resolution of $2 \mathrm{~cm}^{-1}$. Spectra recorded at elevated temperatures $\left(30-250^{\circ} \mathrm{C}\right)$ were obtained at $2{ }^{\circ} \mathrm{C} / \mathrm{min}$.

\section{RESULTS AND DISCUSSION}

The terpolymer(styrene-acrylonitrile-vinyl-2,4-diamino-1,3,5-triazine) forms complementary triple hydrogen bonds with copolymers containing uracil. The former provides donor-acceptor-donor (DAD) hydrogen bonding sites and the later provides acceptor-donor-acceptor (ADA) hydrogen bonding sites. The terpolymer/copolymer blend miscibility was studied by measurement of the glass transition temperature $\left(T_{\mathrm{g}}\right)$ by DSC. FTIR was used to investigate blend miscibility and hydrogen bonding interaction between components of the blending system.

\section{Differential Scanning Calorimetry (DSC) Analysis}

$T_{\mathrm{g}}$ of the terpolymers is as follows: SAN-0, $T_{\mathrm{g}}=109.5^{\circ} \mathrm{C} ; \quad \mathrm{SAN}-10, \quad T_{\mathrm{g}}=128.3^{\circ} \mathrm{C} ; \quad \mathrm{SAN}-20$, $T_{\mathrm{g}}=139.2^{\circ} \mathrm{C} ; \mathrm{SAN}-30, T_{\mathrm{g}}=156.2^{\circ} \mathrm{C}$. Differential scanning calorimetry (DSC) curves of the terpolymers are shown in Figure 1. Glass transition temperature increased with triazine ring content in the terpolymers. Blends of SAN-0 (unmodified SAN) with copolymers containing uracil exhibited two different $T_{\mathrm{g}} \mathrm{s}$, for $\mathrm{SAN}-0 / \mathrm{P} 1$ and SAN-0/P2' blends (Figure 2). The blend systems of SAN-0 with the respective copolymers were immiscible.

SAN was modified by introducing the triazine motif. The blends turned from immiscible to miscible and gave one $T_{\mathrm{g}}$, as shown in Figures $3 \mathrm{a}$ and $3 \mathrm{~b}$. All data

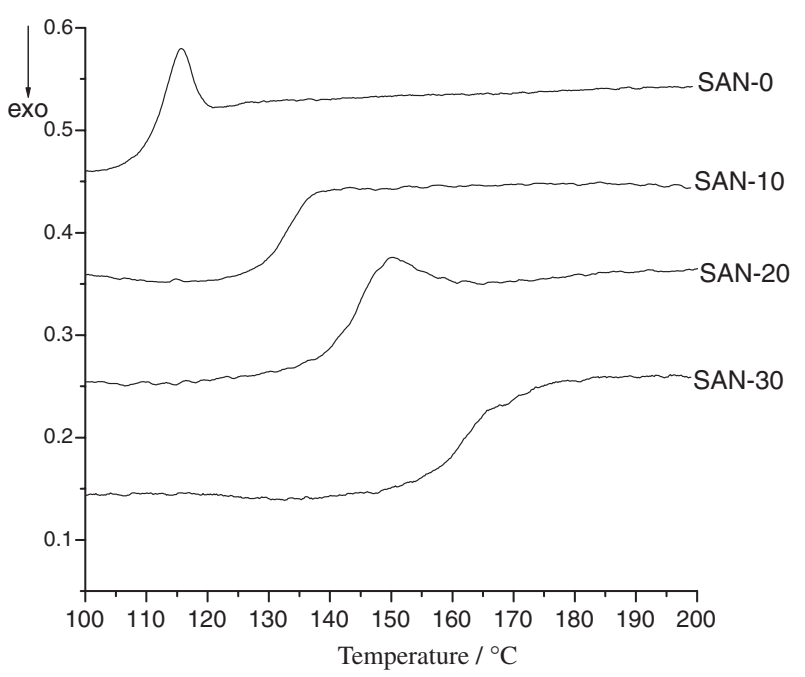

Figure 1. DSC curves of terpolymers containing triazine. 


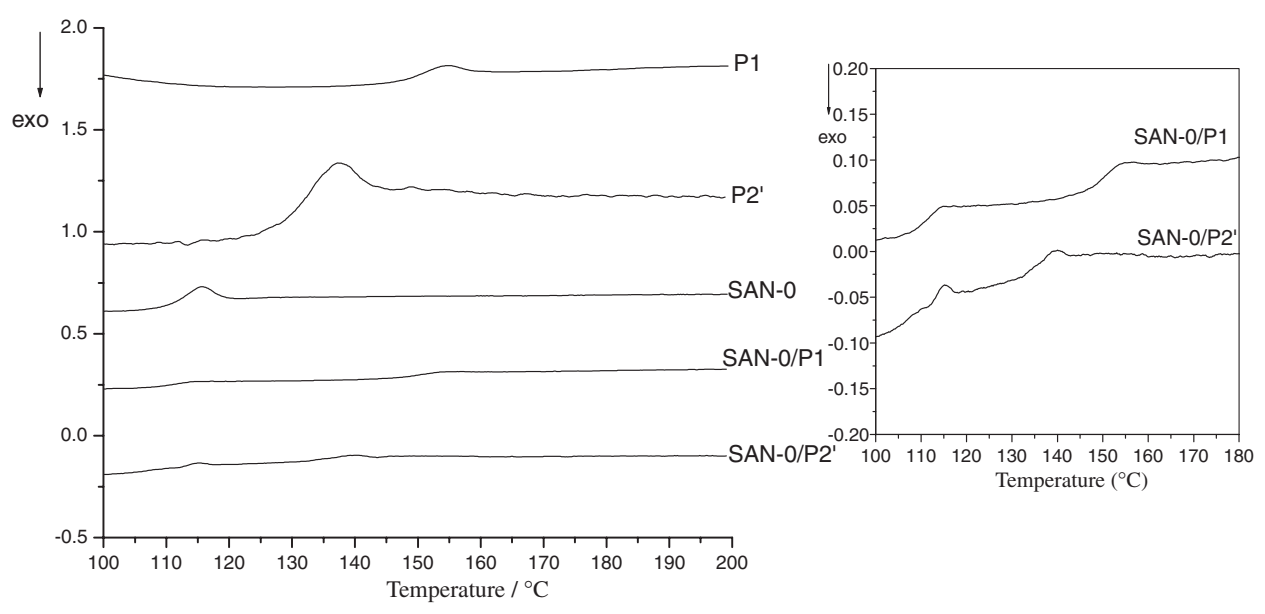

Figure 2. DSC curves of polymers $\mathrm{P} 1, \mathrm{P} 2^{\prime}, \mathrm{SAN}-0$, and their blends $\mathrm{SAN}-0 / \mathrm{P} 1$ and $\mathrm{SAN}-0 / \mathrm{P} 2^{\prime}$.

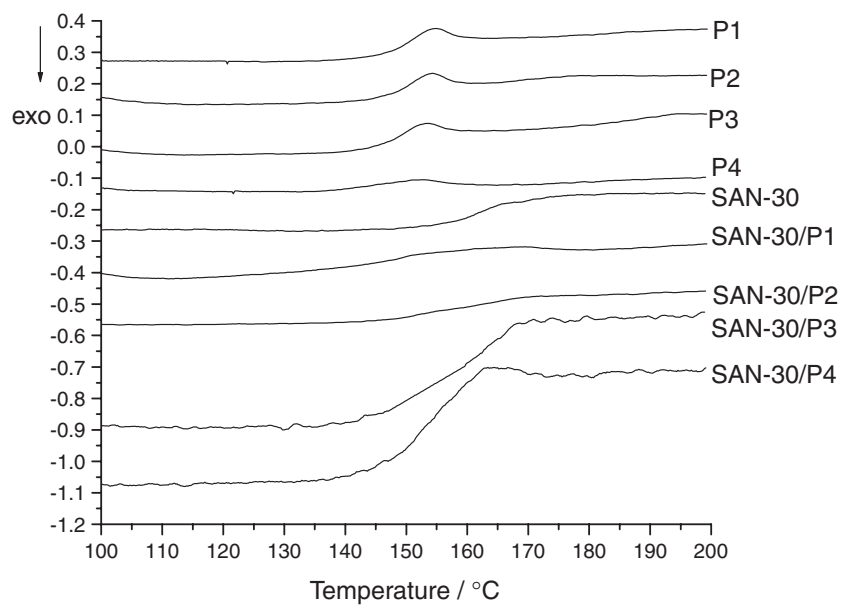

(a)

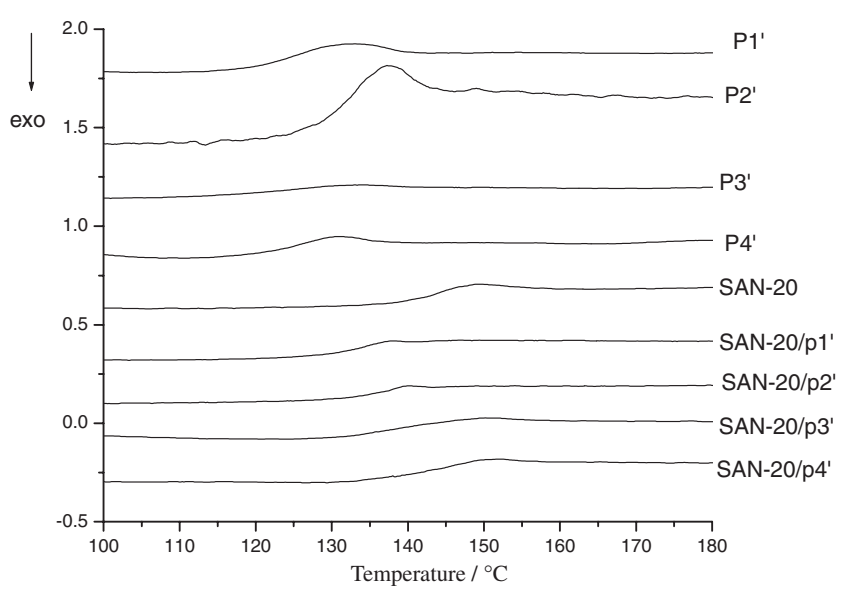

(b)

Figure 3. (a) DSC curves of the copolymers (P1-P4), the terpolymer SAN-30, and their blends. (b) DSC curves of the copolymers $\left(\mathrm{P}^{\prime}-\mathrm{P} 4^{\prime}\right)$, the terpolymer SAN-20, and their blends.

are listed in Table II. The results suggest that the copolymer containing uracil unit forms a strong hydrogen bonds with the terpolymer containing triazine, causing the blend system to the miscible.
Table II. $T_{\mathrm{g}}$ data for terpolymer/copolymer blends

\begin{tabular}{cccccc}
\hline Blend & $T_{\mathrm{g}}\left({ }^{\circ} \mathrm{C}\right)$ & Terpolymer & $T_{\mathrm{g}}\left({ }^{\circ} \mathrm{C}\right)$ & Copolymer & $T_{\mathrm{g}}\left({ }^{\circ} \mathrm{C}\right)$ \\
\hline SAN-30/P1 & 152.5 & SAN-30 & 156.2 & $\mathrm{P} 1$ & 146.3 \\
SAN-30/P2 & 150.9 & SAN-30 & 156.2 & $\mathrm{P} 2$ & 146.2 \\
SAN-30/P3 & 146.4 & SAN-30 & 156.2 & $\mathrm{P} 3$ & 144.4 \\
SAN-30/P4 & 145.2 & SAN-30 & 156.2 & $\mathrm{P} 4$ & 137.7 \\
SAN-20/P1 & 128.7 & SAN-20 & 139.2 & $\mathrm{P}^{\prime}$ & 118.4 \\
SAN-20/P2 $^{\prime}$ & 132.8 & SAN-20 & 139.2 & $\mathrm{P}^{\prime}$ & 127.2 \\
SAN-20/P3 $^{\prime}$ & 131.2 & SAN-20 & 139.2 & $\mathrm{P}^{\prime}$ & 114.9 \\
SAN-20/P4' & 134.6 & SAN-20 & 139.2 & $\mathrm{P}^{\prime}$ & 119.2 \\
\hline
\end{tabular}

\section{FTIR Analysis}

The infrared spectra of the copolymer P1, terpolymer SAN-30, and 50/50 blend SAN-30/P1 at room temperature are shown in Figure 4a. In the spectrum of terpolymer SAN-30, two peaks at 3500 and $3328 \mathrm{~cm}^{-1}$ of the amino stretching band are attributed to free and self-associated amino groups of SAN-30, respectively, and the peak at $3395 \mathrm{~cm}^{-1}$ was assigned to an amino group symmetric stretch vibration. ${ }^{34}$ From the spectrum of blend SAN-30/P1, the free amino peak shifts to $3475 \mathrm{~cm}^{-1}$, lowering by $25 \mathrm{~cm}^{-1}$ and the self-associated amino band also shifts to a lower frequency at $3320 \mathrm{~cm}^{-1}$, indicating that some free amino groups of SAN-30 to form hydrogen bonds with P1 after mixing of SAN-30 with P1, and some originally self-associated amino groups of SAN-30 are disassociated and instead hydrogen bonds with P1. In the carbonyl stretching region, the band at $1710 \mathrm{~cm}^{-1}$ is attributed to the carbonyl groups of copolymer $\mathrm{P} 1$, and the blend with SAN-30 shows no significant wavenumber change of the carbonyl band around $1710 \mathrm{~cm}^{-1}$, due to multiple carbonyl groups (amide, imide and ester) in P1, resulting in a very strong and broad carbonyl absorbance band.

Hydrogen bonding between the two polymers was further investigated by measuring temperaturedependent spectral changes for the blend (Figure $4 b$ ). With increase in temperature, the free amino peak 

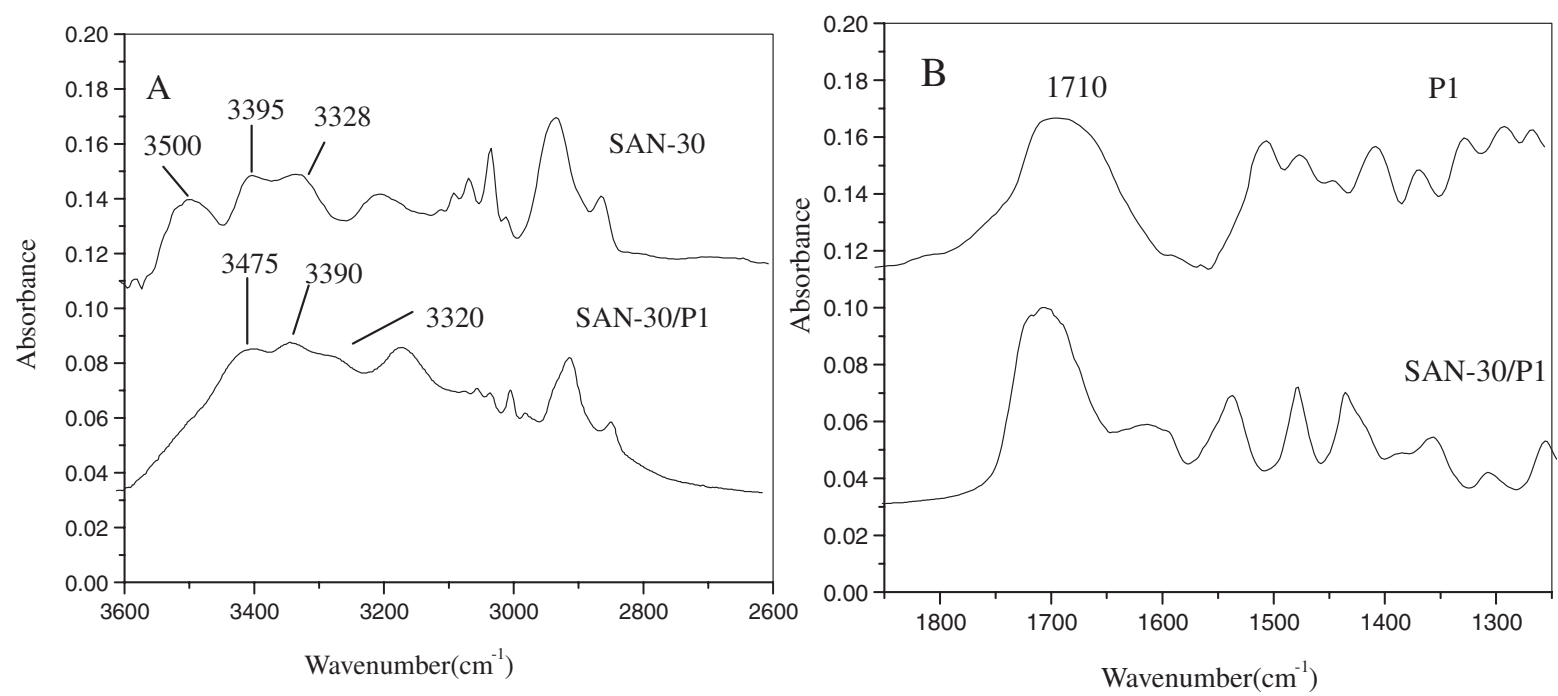

(a)
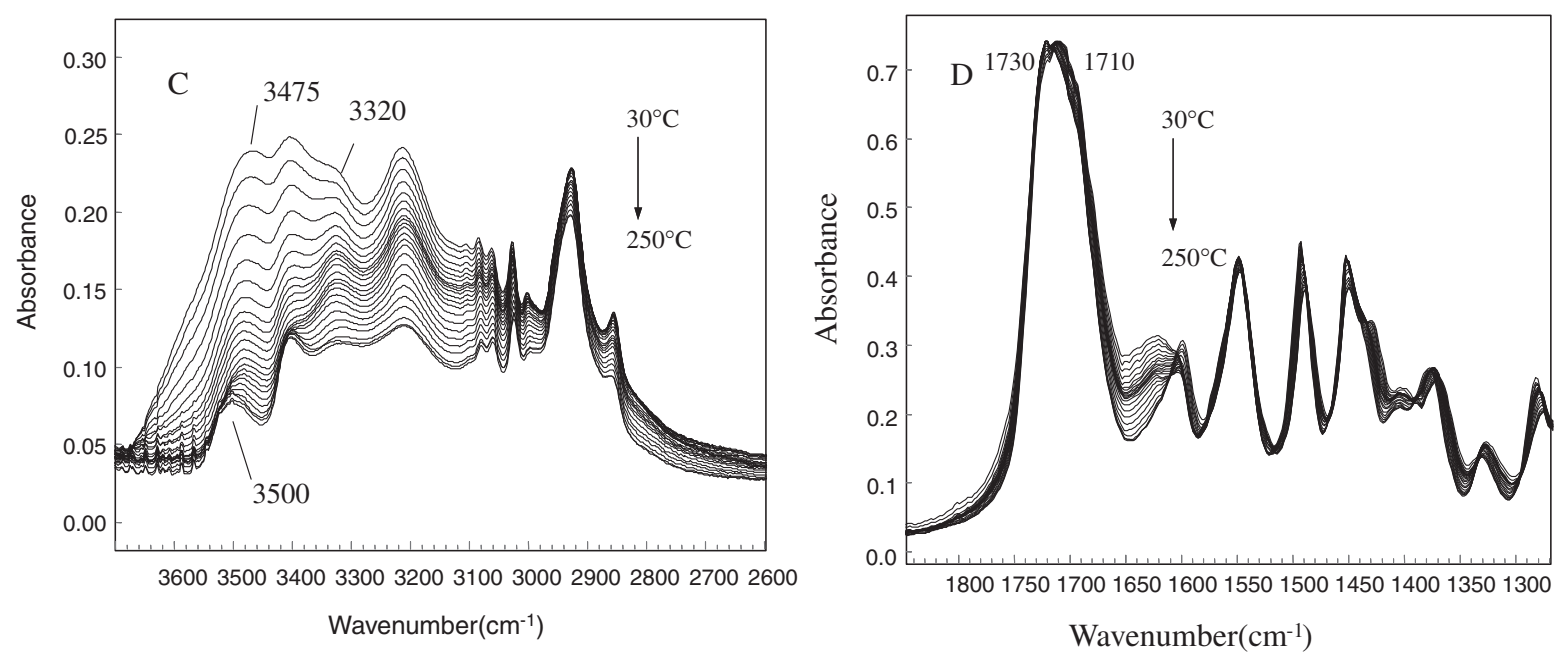

(b)

Figure 4. (a) IR spectra of copolymer P1, terpolymer SAN-30, and their blend SAN-30/P1. A, the amino group stretching region; B, the carbonyl stretching region. (b) Effect of increasing temperature on the IR spectra of blend SAN-30/P1. C, the amino group stretching region; $\mathrm{D}$, the carbonyl stretching region.

shifted from 3475 to $3500 \mathrm{~cm}^{-1}$, becoming more prominent, while the intensity of hydrogen bonded amino stretching peak at $3320 \mathrm{~cm}^{-1}$ decreases, and a part of the carbonyl group band at $1710 \mathrm{~cm}^{-1}$ shifted to a higher frequency at $1730 \mathrm{~cm}^{-1}$. This confirms the existence of hydrogen bonds in the blend SAN-30/P1 and that hydrogen bonds are destroyed if temperature is increased. A possible triple hydrogen bond interaction between the triazine ring in the terpolymer and uracil unit in the copolymer is suggested in Scheme $4 .^{8,35}$

Figure 5a shows infrared spectra of the copolymer $\mathrm{P} 2$ ', terpolymer SAN-20, and 50/50 blend SAN-20/ $\mathrm{P}^{\prime}$. In the spectrum of SAN-20, the peak at $3510 \mathrm{~cm}^{-1}$ is assigned to free $\mathrm{NH}_{2}$ absorbance, and the peak at $3330 \mathrm{~cm}^{-1}$ is attributed to self-associated $\mathrm{NH}_{2}$ in SAN-20. In the spectrum of blend SAN-20/ $\mathrm{P} 2^{\prime}$, peaks at $3510 \mathrm{~cm}^{-1}$ and $3330 \mathrm{~cm}^{-1}$ shift to
$3490 \mathrm{~cm}^{-1}$ and $3320 \mathrm{~cm}^{-1}$ respectively, which shows that when SAN-20 is mixed with $\mathrm{P} 2^{\prime}$, some amino groups in SAN-20 form hydrogen bonds with $\mathrm{P} 2$ '. The temperature dependent spectral change for the blend was measured (Figure 5b). With increase in temperature, the free amino absorbance peak at $3490 \mathrm{~cm}^{-1}$ shifts to $3510 \mathrm{~cm}^{-1}$, and in a frequency region higher than $1700 \mathrm{~cm}^{-1}$, the peak at $1730 \mathrm{~cm}^{-1}$ becomes more prominent. IR spectroscopy shows that intermolecular hydrogen bonds are formed between amide carbonyl groups of $\mathrm{P} 2{ }^{\prime}$ and amino groups of SAN-20.

\section{CONCLUSION}

New methacrylate derivatives containing uracil were synthesized and their copolymers with methyl methacrylate were prepared. Blends of poly(styrene- 


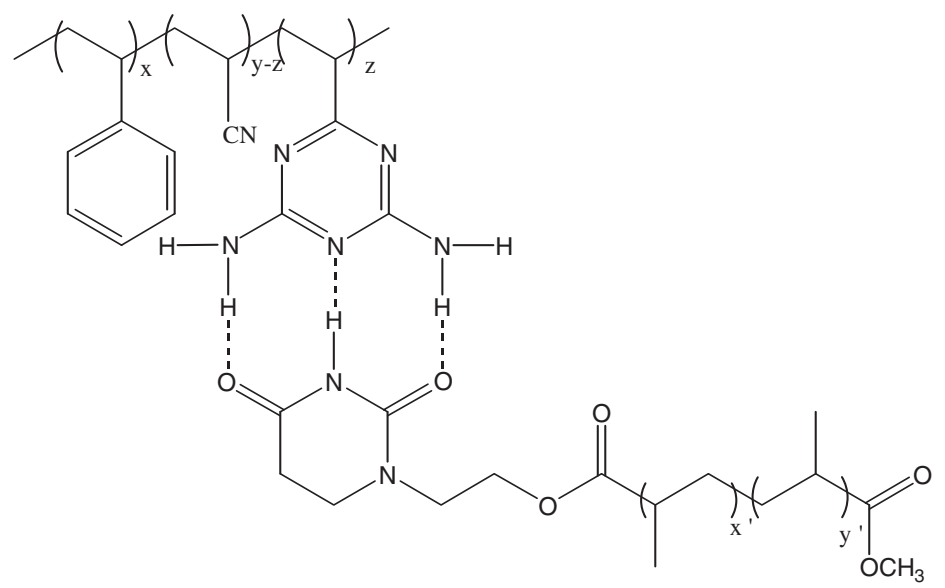

Scheme 4. Triple hydrogen bond interaction between the triazine ring in terpolymer SAN-30 and the uracil unit in copolymer P1.
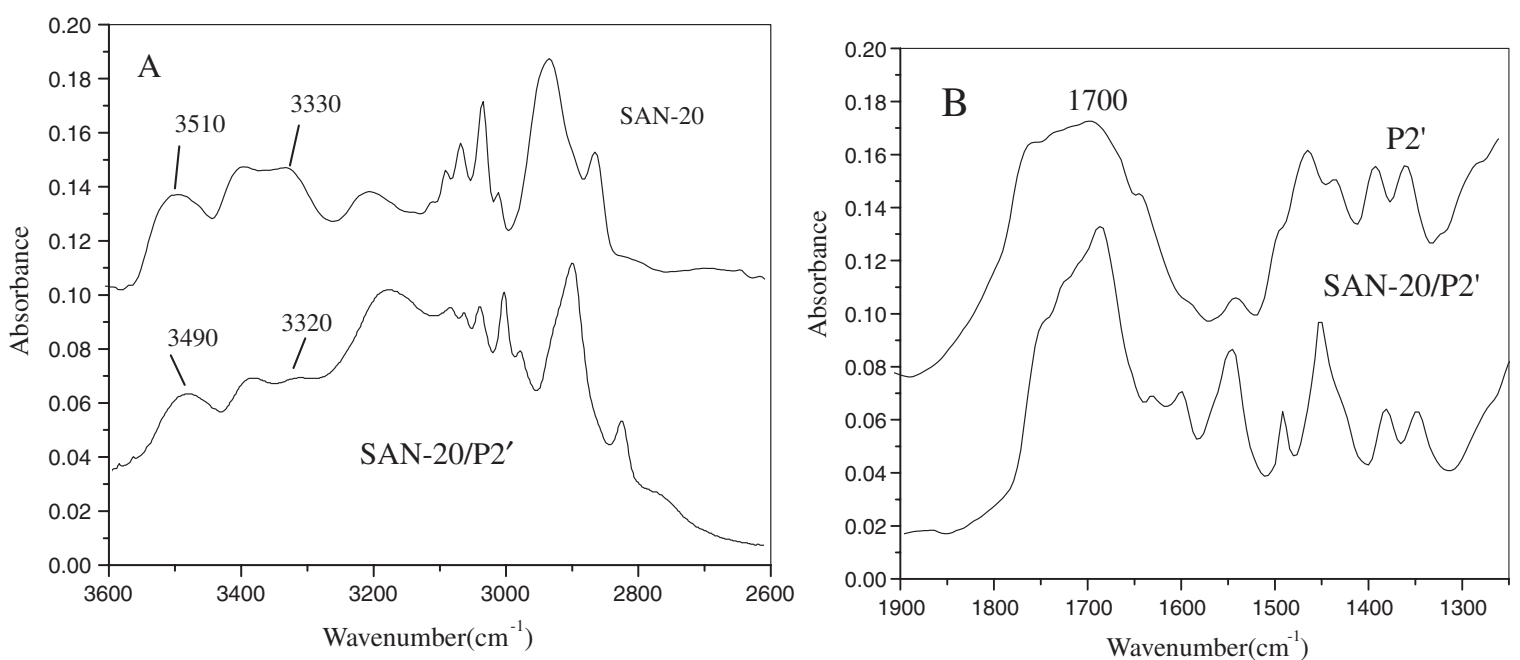

(a)
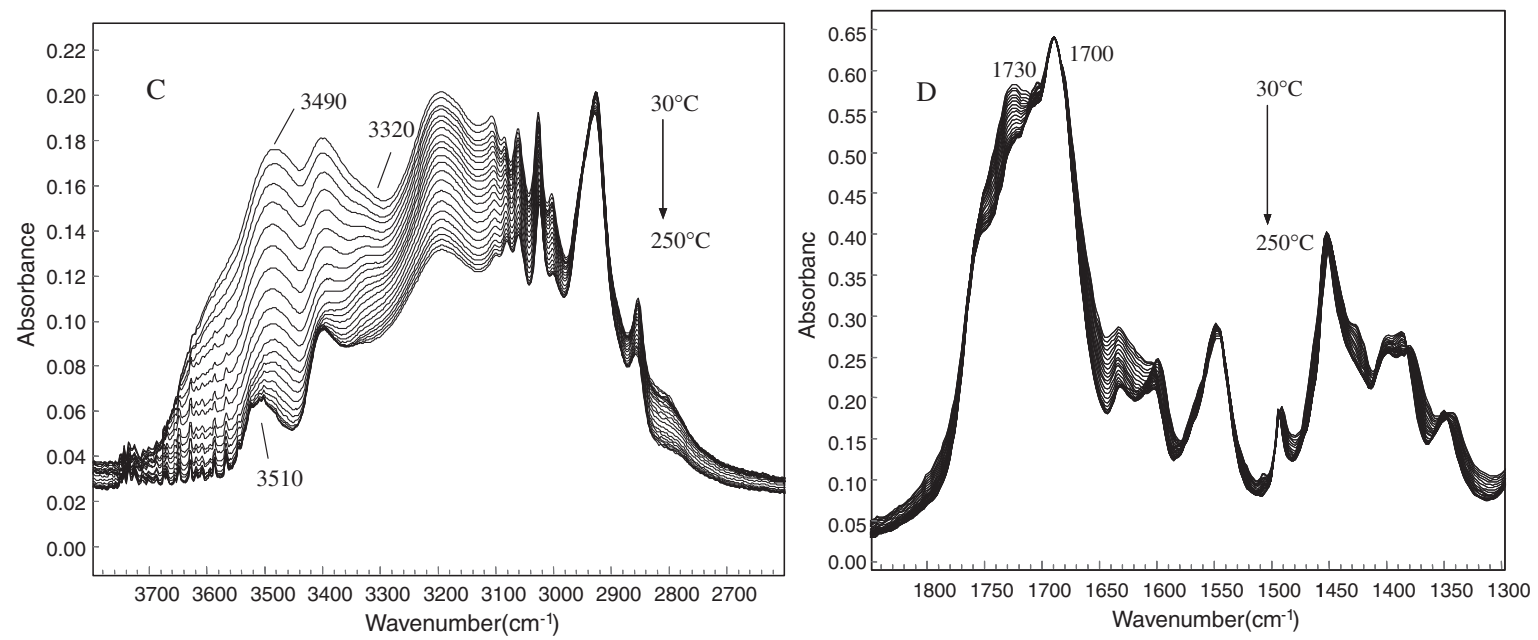

(b)

Figure 5. (a) IR spectra of copolymer $\mathrm{P} 2^{\prime}$, terpolymer SAN-20, and their blend SAN-20/P2 ${ }^{\prime}$. A, the amino group stretching region; $\mathrm{B}$, the carbonyl stretching region. (b) Effect of increasing temperature on the IR spectra of blend SAN-20/P2'. C, the amino group stretching region; $\mathrm{D}$, the carbonyl stretching region.

acrylonitrile) (SAN) and the copolymer containing uracil were not miscible. When SAN was modified to contain 2,4-diamino triazine, the blend turned misci- ble and had a single $T_{\mathrm{g}}$, indicating that the triazine ring of the terpolymer and uracil of the copolymers form strong hydrogen bonds. IR spectra further con- 
firmed the formation of hydrogen bonds between the copolymers and the terpolymer, suggesting this interaction to be the main driving force for miscibility.

Acknowledgment. We are grateful to State Key Fundamental R and D projects (G1999064207) and Foundation for University Key Teacher by the Chinese Ministry of Education for financial support of this work. We acknowledge the useful discussions with Dr. Hesheng Zhang, Tianjin Hermay Bio-Tech Co., Ltd.

\section{REFERENCES}

1. D. J. T. Hill, A. K. Whittaker, and K. W. Wong, Macromolecules, 32, 5285 (1999).

2. S. H. Goh, W. W. Y. Lau, and C. S. Lee, Polym. Bull., 29, 521 (1992).

3. X. Qiu and M. Jiang, Polymer, 36, 3601 (1995).

4. E. M. Pearce, T. K. Kwei, and J. Min, Macromol. Sci. Chem. A, 21, 1181 (1984).

5. M. Aubin, R. Voyer, and R. E. Prud'homme, Makromol. Chem. Rapid Commun., 5, 419 (1984).

6. M. M. Coleman, J. F. Graf, and P. C. Painter, "Specific Interactions and the Miscibility of Blends," Technomic, Lancaster, PA, 1991.

7. J. M. G. Cowie and A. N. N. Reilly, Eur. Polym. J., 29, 455 (1993).

8. J. M. G. Cowie and D. Cocton, Polymer, 40, 227 (1998).

9. J. M. G. Cowie and C. Love, Polymer, 42, 4783 (2001).

10. A. S. Michaels and R. G. Miekka, J. Phys. Chem., 65, 1765 (1961).

11. N. Ohno and J. Kumanotani, Polym. J., 11, 947 (1979).

12. H. A. Schneider, H. J. Cantow, and V. Percec, Polym. Bull., 6, 617 (1982).

13. A. Eisenberg, P. Smith, and Z. L. Zhou, Polym. Eng. Sci., 22, 1117 (1982).

14. P. Smith and A. Eisenberg, J. Polym. Sci. Polym. Lett. Ed., 21, 223 (1983).
15. S. D. Clas and A. Eisenberg, J. Polym. Sci. Polym. Phys. Ed., 22, 1529 (1984).

16. E. J. Moskala, S. E. Howe, P. C. Painter, and M. M. Coleman, Macromolecules, 17, 1671 (1984).

17. J. Y. Lee, P. C. Painter, and M. M. Coleman, Macromolecules, 21, 346 (1988).

18. J. Y. Lee, P. C. Painter, and M. M. Coleman, Macromolecules, 21, 954 (1988).

19. A. M. Lichrus, P. C. Painter, and M. M. Coleman, Macromolecules, 21, 2636 (1988).

20. R. Stadler and J. Burgert, Makromol. Chem., 187, 1681 (1986).

21. C. Hilger and R. Stadler, Macromolecules, 23, 2097 (1990).

22. J. Rebek, Pure Appl. Chem., 61, 1517 (1989).

23. K. Takemoto, M. Akashi, and Y. Inaki, J. Polym. Sci. Polym. Chem. Ed., 12, 1861 (1974).

24. M. J. Moghaddam, S. Hczumi, Y. Inaki, and K. Takemoto, Polym. J., 21, 203 (1989).

25. K. Takemoto and Y. Inaki, Adv. Polym. Sci., 41, 1 (1981).

26. Y. Q. Duan, X. H. Liu, X. H. Gao, C. X. Li, G. H. Li, and B. L. He, Chem. J. Chin. Univ., 10, 214 (2001).

27. J. M. G. Cowie and D. Cocton, Polymer, 40, 227 (1999).

28. M. M. Coleman and P. C. Painter, Appl. Spectrosc. Rev., 20, 255 (1984).

29. L. J. Yee, P. C. Painter, and M. M. Coleman, Macromolecules, 21, 346 (1988).

30. C. B. Herbert, J. Am. Chem. Soc., 60, 1325 (1938).

31. Y. Inaki, S. Fukunaga, Y. Suda, and K. Takemoto, J. Polym. Sci. Polym. Chem. Ed., 24, 119 (1985).

32. X. J. Liu, G. C. Chi, and R. Y. Chen, Chin. J. Synth. Chem., 7, 219 (1999).

33. M. Bosma, G. Brinke, and T. S. Ellis, Macromolecules, 21, 1465 (1988).

34. F. H. Beijer, "Cooperative Multiple Hydrogen Bonding in Supramolecular Chemistry," Doctoral dissertation, Technische Universiteit Eindhoven, Eindhoven, 1998.

35. F. H. Beijer, R. P. Sijbesma, J. A. J. M. Vekemans, E. W. Meijer, H. Kooijman, and A. L. Spek, J. Org. Chem., 61, 6371 (1996). 